\title{
Household Energy Consumption Patterns in Sri Lanka
}

\author{
K. Rajmohan and J. Weerahewa*
}

\begin{abstract}
This study examines the pattern of household energy consumption among urban, rural and estate sectors, over time and across income groups in Sri Lanka. The 'energy ladder' hypothesis was tested and Engle functions were estimated using Consumer Finances and Socio Economic Survey data from 1978/79 to 2003/04. Results reveal that the energy ladder hypothesis holds for Sri Lanka and the country as a whole is moving towards modern fuels such as liquefied petroleum gas (LPG) and electricity. The urban sector proceeds much faster than the rural sector. Engle functions estimated for individual fuels and for different sectors reveal that the budget elasticity values were negative for firewood and kerosene, in the urban and estate sectors, indicating that they are inferior goods. LPG and electricity had positive budget elasticities indicating that they are normal goods. Budget elasticities estimated for the estate sector were insignificant eliciting that factors other than income influence the fuel consumption decisions.
\end{abstract}

\section{Introduction}

The recent supply disruptions in the international crude oil market followed by the escalating prices of crude oil have prompted policy makers in oil importing countries to face the challenge of coping with higher oil prices (International Energy Agency, 2005). The degree to which oil pice influence such economies depends mainly on the energy policies adopted, pricing mechanism implemented, the structure of the energy markets and the degree to which the international price changes are transmitted. Sri Lanka is also a victim of the higher oil prices in the international market due to its high dependence on petroleum imports. The increasing demand for petroleum products for electricity generation, transportation, industrial production and domestic needs has made the Sri Lankan economy more vulnerable to oil price shocks.

Sri Lanka, with relatively poor endowment of renewable energy sources and unexplored fossil fuel sources, has well recognized the

Authors are, respectively, Former Temporary Assistant Lecturer and Senior Lecturer, Department of Agricultural Economics and Business Management, Faculty of Agriculture, University of Peradeniya, Sri Lanka. 
obstructions with respect to commercial energy consumption. In order to minimize the burden on the economy, the government of Sri Lanka has taken a variety of measures including price stabilizing policies and tax and subsidy reforms over the past few decades. The government of Sri Lanka documented its energy policy in the National Energy Policy and Strategies for Sri Lanka in 2006. The key objectives of the stated policy are providing basic energy needs, ensuring energy security, promoting indigenous resources, enhancing energy sector management capacity, consumer protection while ensuring a level playing field and protection from adverse environmental impacts arising through development and operation of energy facilities. These objectives are coupled with a number of implementing strategies in the energy sector.

In order to design strategies to achieve above policy objectives a detailed knowledge of the energy consumption pattern of households in Sri Lanka is vital. However, very little is known about the energy consumption pattern of households in Sri Lanka. This article addresses this gap by (i) identifying the fuel consumption pattern of urban, rural and estate sector households of Sri Lanka over time, and (ii) identifying the income responsiveness of households by estimating Engle functions.

The paper first provides the background in which the study was carried out and discusses the past studies that were done in analyzing energy demand. The paper next deals with models and data. The empirical findings are presented next followed by concluding remarks.

\section{A Historical Overview of Energy Usage in Sri Lanka}

During the pre-modern era, Sri Lankan energy requirements for heating, lighting and drying relied on plant based combustible substances. With the arrival of new technology in the mid-19th century, the range of energy sources expanded due to the importation of modern energy sources such as coal, naphtha and petroleum products, which subsequently replaced the traditional fuels either partly or fully in different sub-sectors. The share of hydroelectricity, biomass and petroleum consumed in Sri Lanka was 5\%, 70\% and $25 \%$ respectively in 1972 while it was $8 \%, 45 \%$ and $47 \%$ respectively in 2006, showing a drastic drop in the share of biomass and a rise in petroleum products (Central Bank of Sri Lanka, 2006). The use of other renewable energy sources such as solar electricity and wind power constitute insignificant proportions with very low potential of becoming significant sources of energy in the near future.

The quantity of primary energy produced in Sri Lanka is much lower compared to the energy demanded. During the period of 1980-2005, the primary energy production in Sri Lanka has fluctuated between 0.01-0.05 
Quadrillion Btu, while the consumption of primary energy has increased steadily from 0.08 Quadrillion Btu in 1980. According to International Energy Agency (IEA) (2005) statistics the dependence of Sri Lanka on petroleum products was approximately $82 \%$ of the commercial energy sources in 2002 .

The Sri Lankan residential energy consumption mainly relies on firewood, kerosene, LPG and electricity. According to the IEA, the residential energy consumption in Sri Lanka has increased from $4.1 \%$ of the total energy consumption in 1990 to $5.2 \%$ in 2001. Meeting the increasing demand for household energy has become a major problem due to inadequate capacity building, lower efficiency in consumption and delivery, increasing dependency on imported fuels along with increasing fuel costs. Further, in spite of the increasing crude oil prices in the world market, the demand for petroleum products has observed an increasing trend while aggravating the burden to the government with the increasing cost on energy subsidies.

The use of petroleum products for thermal power generation has increased in 2007 compared to 2006. Of the total electricity generated in Sri Lanka, hydroelectricity has decreased from $49 \%$ to $40 \%$ during the same period. Thus, in 2007, fossil fuel based power plants accounted for $60 \%$ of the electricity generated and this consumes approximately $30 \%$ of the petroleum sales of the country (Central Bank of Sri Lanka, 2007). This has reduced the capability of the state owned Ceylon Electricity Board (CEB), to generate power at a lower cost. Consequently, the burden to the government, electricity intensive industries and the domestic consumers has been aggravated. Eventually the government of Sri Lanka is facing the challenge of neutralizing the situation with appropriate policy options and demand management systems.

Further, environmental degradation due to deforestation, desertification and the consumption of energy sources, health hazards due to the consumption of biomass fuels and distributional concerns are emerging issues with the rising demand for energy. These issues eventually have ensued serious welfare impacts on households.

\section{Past Studies}

The demand for various sources of energy has been analyzed theoretically and empirically using different approaches. They include the energy ladder hypothesis (Kebede et al., 2002; Arnold et al., 2006; Davis, 1998; Masera et al., 2000; Barnett, 2000), the Engle curves (Amacher et al., 1993, 1996, 1999; Mekonnen, 1999; Helberg et al., 2000; Gundimeda and Kohlin, 2003; Baland et al., 2005), and energy demand functions (Athukorala 
et al., 2007; Erdogdu, 2006). These studies have considered different factors that influence the energy demand patterns according to the context and have analyzed the energy demand both at micro and macro levels. Discussion of the impacts of income and price on the energy demand were of main interest in these studies, while extensions were made to study other factors that influence the energy demand.

The energy ladder hypothesis is one of the most common approaches used in studying the household energy use patterns. The concept of energy ladder hypothesis states that people with low incomes generally use traditional fuels as their main cooking fuel and people with higher incomes tend to use modern fuels. Results of the energy demand studies reveal that the income, fuel prices, government policies and household characteristics influence energy consumption levels. There is evidence to show that people in urban areas use more kerosene, LPG, and electricity. They also suggest that price-based and quantity-based government policies tend to influence the urban fuel demand patterns more than does the household income level (Bhatia, 1988).

A great part of the literature has been dedicated for applying energy demand functions in different energy sub sectors, in different countries. Kebede et al., (2002) carried out a study to examine the affordability of modern fuels (electricity, butane gas and kerosene) by the urban poor in Ethiopia. The demand equations were econometrically estimated for each fuel and elasticities were used to examine price and income effects. A multivariate analysis was performed using cross-sectional data, to estimate the demand patterns where the budget shares of each fuel was regressed on the total household expenditures, prices of fuels and the household size. Results showed that all fuels considered had positive income elasticities. The signs of own price elasticities were consistent with the economic theory.

Another study done by Athukorala et al., (2007), in estimating the household demand for electricity in Sri Lanka used two models, by which the importance of household characteristics and the influence of selected macroeconomic variables were investigated. The first model was estimated using panel data within the Kandy municipality. A log-log demand function was found to be the proper specification taking marginal price, difference price, household income level, household size, number of appliances, kerosene price and gas price as the independent variables. The findings on income elasticity suggested that electricity is a normal good and has an inelastic demand in the Kandy area. The estimated cross price elasticity elicits that electricity is a complement to both gas and kerosene. The second model was estimated using the co-integration and error correction technique where the short run and long run equilibrium elasticities of demand were 
investigated using aggregate time series data. The variables that were investigated were per capita real GDP, average real electricity price and real kerosene price. According to this aggregate analysis, positive sign of the cross price elasticity between electricity and kerosene indicated the possibility of substituting electricity with kerosene in the long run and the short run in Sri Lanka.

Chambwera (2004) investigated the consumer demand for energy using household energy mix model. Following Deaton and Muellbauer (1980), he used a two stage budgeting process undertaken by the consumers in the process of decision making. It was assumed that the expenditure of a consumer is first allocated to a broad group of commodities and then suballocated to specific commodities in that group in subsequent stages.

An Almost Ideal Demand Systems (AIDS) model was empirically estimated in Harare - Zimbabwe, in linear approximate form incorporating other household characteristics in addition to income and prices by Chambwera (2004). Other household characteristics tested were household income, household size, household size square, housing space, energy appliances, level of education, occupancy, employment, gender and ownership of the house.

\section{Models and Data}

\section{The Energy Ladder Hypothesis}

The choice of a fuel by households depends on own price, the prices of the related fuels, appliances used, the efficiency of the fuels and household characteristics. One of the main factors that determine the selection of a fuel and the movement towards other alternatives is the income of the households. As stated earlier, the energy ladder hypothesis explains the movement of energy consumption from traditional sources to more sophisticated sources along an imaginative ladder with the improvement in the economic (income) status of households. The energy ladder is presented in Figure 1 (Masera et al., 2000).

The underlying assumption of the model is that households are exposed to a number of fuel choices which could be arranged in an order of increasing technological sophistication. Biomass fuels occupy the bottom of the list while electricity, that is much cleaner, lies at the top. It is assumed that energy transition occurs from the bottom to the top with increasing socioeconomic status of households either through a rise in income or a fall in price (Hosier and Dowd, 1987). This concept is expected to align with the cross sectional and longitudinal variations in income. 
Figure 1: $\quad$ Schematic diagram of the energy ladder

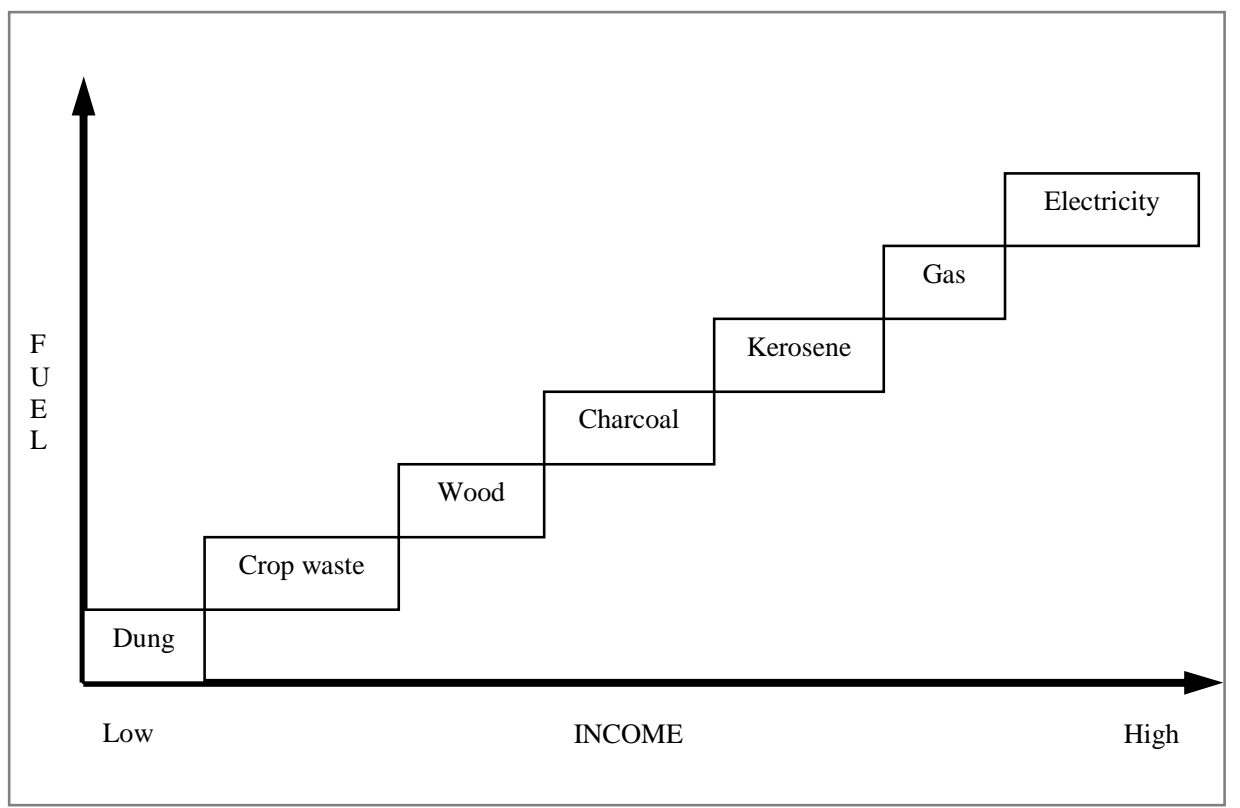

It should be noted that the concept of energy ladder hypothesis is loosely based on economic theory of consumer behavior (Hosier and Kipondya, 1993). It explains the theory partly, showing when income increases households not only consumes more of the same good but they also shift to more sophisticated goods with higher quality. Further it assumes that cleaner fuels are normal economic goods while traditional fuels are inferior.

The major sources of energy consumed at the household level in Sri Lanka are firewood, kerosene, LPG and electricity. Thus the hypothetical energy ladder at the micro level for Sri Lanka constitutes of firewood, kerosene, LPG and electricity. Firewood occupies the bottom rung of the ladder while electricity is at the top. It is assumed that with the improvement in economic status of households, they would shift towards modern fuels.

This paper tests the relevance of the energy ladder hypothesis to Sri Lanka, by comparing the energy budget share of individual fuels for the urban, rural and estate sectors over time. Attempts were made to provide a general description of the fuel consumption pattern both in a cross-sectional and longitudinal manner. Also the overall average energy budget shares of fuels were used to make comparisons at the level of sectoral aggregation. 


\section{Engle Function}

The Engle curve explains the relationship between the quantity of a good demanded and the income of the consumer, keeping all the prices held constant levels. Budget elasticities calculated using the coefficients estimated in the Engle function, are free measures of responsiveness of quantities demanded to a change in the total budget. They are used to categorize commodities as inferior goods, necessities or luxuries. This enables economists make meaningful comparisons at various contexts.

In this study, Engle functions were estimated for the urban, rural and estate sectors separately and for all island averages taking into consideration the theory of separability and step-wise budgeting. It was assumed that households first make their decision on the allocation of the total budget on total energy expenditure and then decide how much to allocate on individual fuels within the energy budget. In this study the second stage of the step-wise budgeting was tested empirically by estimating Engle curves using the functional form;

$$
W_{i}=\alpha+\beta(\ell n T E E)
$$

where, $\mathrm{W}_{i}=$ Energy budget share of fuel $i$,

TEE $=$ Total energy expenditure, and

$\alpha$ and $\beta=$ Parameters to be estimated

Engle curves were estimated for firewood, kerosene, LPG and electricity separately for all island averages and the urban, rural and estate sectors. The semi- logarithmic model is regarded to be the best suit for empirical estimations of Engle functions (Prais and Houthakker, 1955). The statistical software used for the estimation was STATA version 8 .

Budget elasticities $\left(\eta_{i}\right)$ for individual fuels, across sectors and over time were calculated by dividing the estimated coefficient $\beta$ by the energy budget share (Sadoulet and Janvry, 1995).

\section{Data}

The data source used for the empirical analysis is the Consumer Finances and Socio Economic Survey reports of survey years 1978/79, 1981/82, 1986/87, 1996/97 and 2003/04. Data pertaining to different sectors and households in different income groups were considered for the analysis. Survey data were given under eleven income groups during 1978/79, 1981/82, $1986 / 87$ and 1996/97 while the data of 2003/04 were classified for income 
deciles. All households in the country (except Northern and Eastern Provinces) were grouped into three sectors, i.e. urban, rural and estate. The urban sector consists of households in the municipal and urban council areas. The estate sector consists of all households in tea, rubber and coconut estates with 20 or more acres and with 10 or more resident workers. The rural sector was specified to be consisting of all households that are not included under the urban and estate sectors.

The average monthly expenditure of households on individual fuels was used for the analysis during 1978/79, 1981/82, 1986/87, 1996/97, and 2003/04. The expenditure on firewood, kerosene, LPG and electricity at different income classes were the data extracted. The total energy expenditure was calculated by adding the expenditures on individual fuels.

\section{Results and Discussion}

\section{Household Expenditure on Energy}

Table 1 shows the average monthly expenditure on energy for households in different sectors by different income groups and the share of energy as a percentage of the total expenditure in Sri Lanka during 2003/04.

The energy share as a percentage of the total expenditure decreases with the increasing income for all three sectors suggesting that with increasing income levels people tend to use more energy efficient technologies, while reducing the total energy cost. The urban sector spends the highest share on energy, followed by the rural sector for all the income deciles. This could be due to increasing usage of energy consuming appliances with increasing living standards.

\section{Energy Ladder Hypothesis}

\section{Comparison across years}

All sectors: Figure 2 shows how energy transition has taken place in average Sri Lanka. The different bars represent different income classes as per the classification of the Department of Census and Statistics. It could be observed that the energy ladder hypothesis holds in the five cross-sections studied. For instance, considering the results of survey year 2003/04, the dependence of the lowest income decile on firewood (51\%) is higher than that of the highest income decile (09\%). The highest income decile consumes more electricity (64\%). It is evident that with increasing income the consumption of firewood and kerosene are decreasing while the consumption of LPG and electricity are increasing. At low levels of income, kerosene is found to be preferred to 
63

firewood, but with rising incomes consumers shift to LPG and electricity. Thus kerosene could be considered as a transitional fuel.

Table 1: $\quad$ Total energy expenditure in different sectors (Rs.)

\begin{tabular}{lrcc}
\hline Income deciles & Urban sector & Rural sector & Estate sector \\
\hline 1 & 155.22 & 112.54 & 104.39 \\
& $(5.56)$ & $(3.53)$ & $(2.97)$ \\
2 & 167.93 & 107.61 & 99.85 \\
& $(3.04)$ & $(1.99)$ & $(1.85)$ \\
3 & 138.54 & 116.09 & 97.86 \\
& $(1.99)$ & $(1.66)$ & $(1.40)$ \\
4 & 158.40 & 116.78 & 96.67 \\
& $(1.84)$ & $(1.36)$ & $(1.14)$ \\
5 & 182.24 & 125.50 & 95.95 \\
& $(1.75)$ & $(1.21)$ & $(0.93)$ \\
6 & 194.66 & 147.10 & 110.26 \\
& $(1.56)$ & $(1.18)$ & $(0.88)$ \\
7 & 237.84 & 155.89 & 113.17 \\
& $(1.53)$ & $(1.01)$ & $(0.75)$ \\
8 & 268.80 & 183.06 & 105.80 \\
& $(1.38)$ & $(0.94)$ & $(0.55)$ \\
9 & 301.71 & 203.10 & 134.05 \\
& $(1.11)$ & $(0.76)$ & $(0.53)$ \\
& 530.44 & 296.02 & 156.56 \\
& $(0.72)$ & $(0.52)$ & $(0.26)$ \\
\hline \multirow{2}{*}{ Mean } & 233.58 & 156.37 & 111.45 \\
& $(2.05)$ & $(1.42)$ & $(1.13)$ \\
\hline & & &
\end{tabular}

Note: Figures in parenthesis are shares of energy expenditure as a percentage of total expenditure. 
Figure 2: Energy budget shares of firewood, kerosene, LPG and Electricity
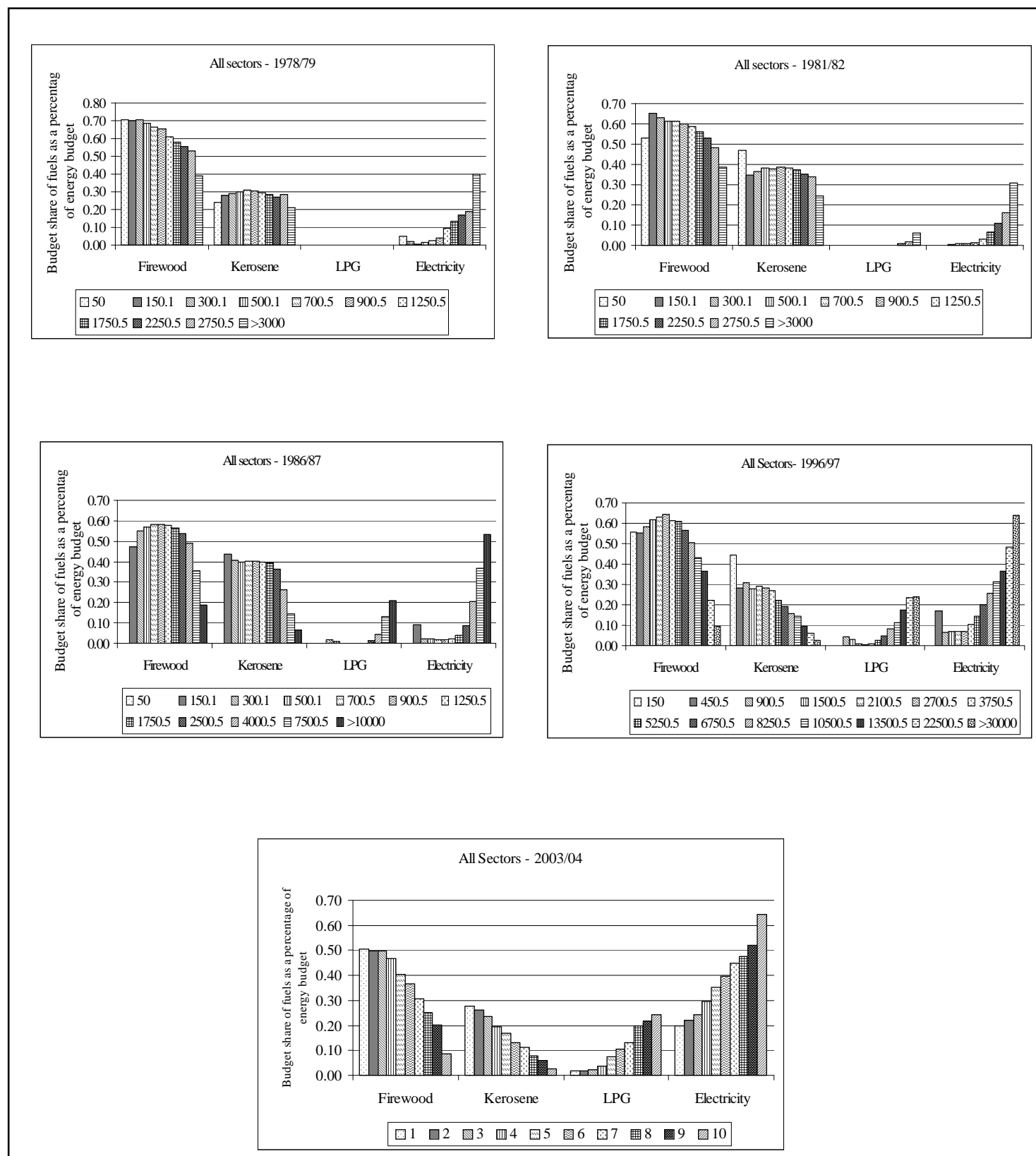
It could also be observed that Sri Lanka is moving up the energy ladder longitudinally. Also the pattern of shift follows the energy ladder hypothesis much clearly with time. For example, the share of electricity in the highest income group has increased from $40 \%$ in 1978/79 to 64\% in 2003/04. Similarly the consumption share of cleaner fuels has been increased with time while the share of traditional fuels has been decreased. However, firewood has been the most popular source of household energy among almost all the income groups until 1996/97 except for the higher income groups.

Urban sector: The fuel consumption pattern of the urban sector households over time is presented in figure 3. The energy ladder hypothesis holds crosssectionally and longitudinally for the urban sector of Sri Lanka, while the lowest income groups follow an exceptional pattern with time. The pattern observed among the urban poor indicates that income is not the main factor that determines their energy consumption pattern but, there could be certain other factors that influence their fuel choice.

Rural sector: Figure 4 shows the change in energy choice of the rural sector households in Sri Lanka. According to the results it is obvious that firewood was the most popular source of energy among all the rural sector households in Sri Lanka until 1981/82. The situation has been changing with the increased rate of electrification to the rural sector and the improvement of their economic status. As the concept of energy ladder is closely related to urbanization, it could be justified that the rural sector of Sri Lanka is following the energy consumption pattern of the urban sector with time, while climbing the energy ladder.

Estate sector: Findings for the estate sector are depicted in figure 5. The results reveal that the estate sector still lies at the bottom of the energy ladder. Firewood is the main source of energy among the estate sector households followed by kerosene. Energy transition to modern fuels could be observed only among the highest income groups with time. However, during the most recent survey period a clear shift to modern fuels is observed. This is mainly due to the increased rate of electrification and infrastructure development projects implemented in Sri Lanka.

Survey year 2003/04: Panels E in figures 3, 4 and 5 indicate the difference in the consumption pattern of households in the urban, rural and estate sectors respectively in 2003/04. It could be clearly observed that the urban and rural sectors follow a similar pattern of energy transition during the survey period of 1996/97 and 2003/04. The lower income groups of these sectors mainly rely on traditional fuels while the higher income groups are dependent on cleaner fuels both LPG and electricity. Modern fuels are becoming 
increasingly popular among the urban sector followed by the rural sector while they are still consumed in insignificant proportions in the estate sector.

Figure 3: $\quad$ Energy budget share of fuels - Urban sector

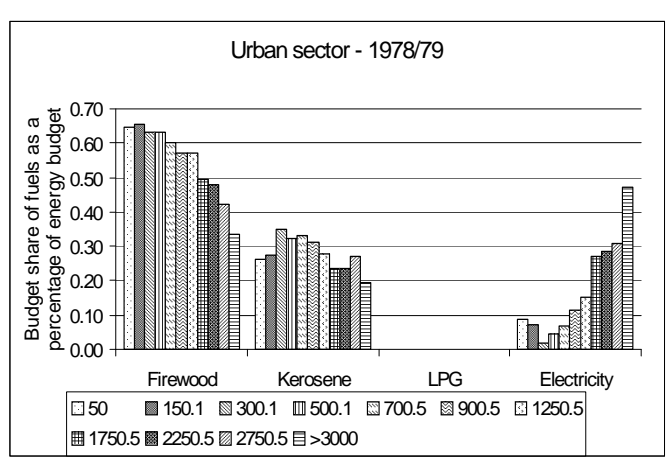

A

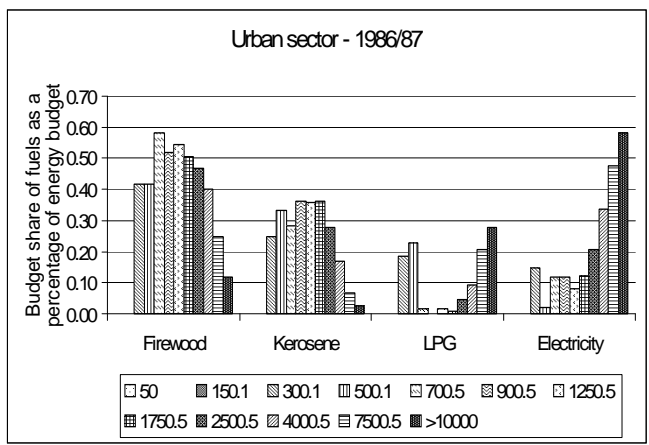

$\mathrm{C}$

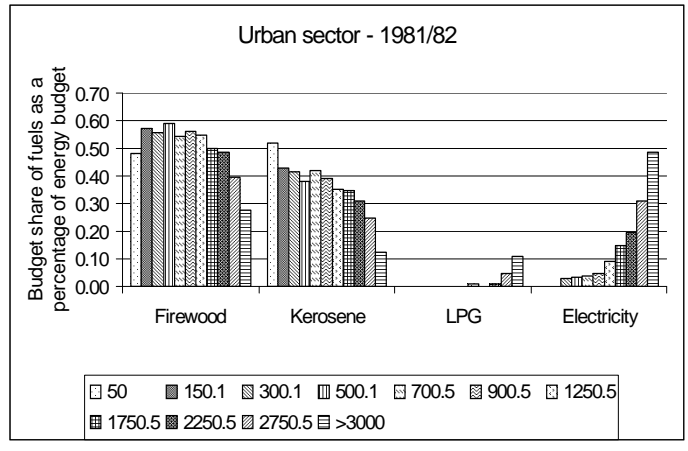

B

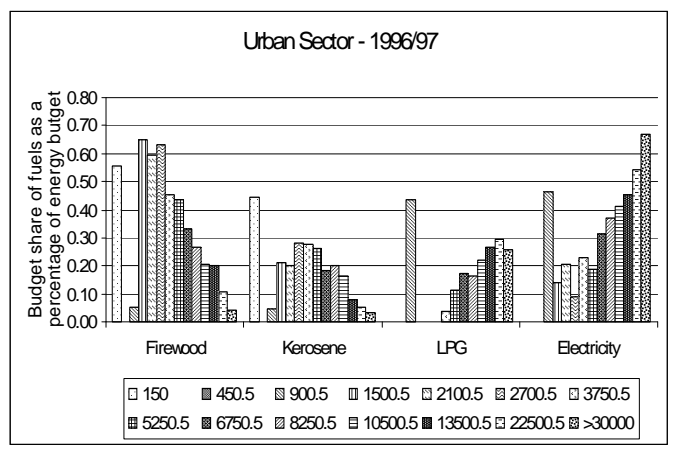

$\mathrm{D}$

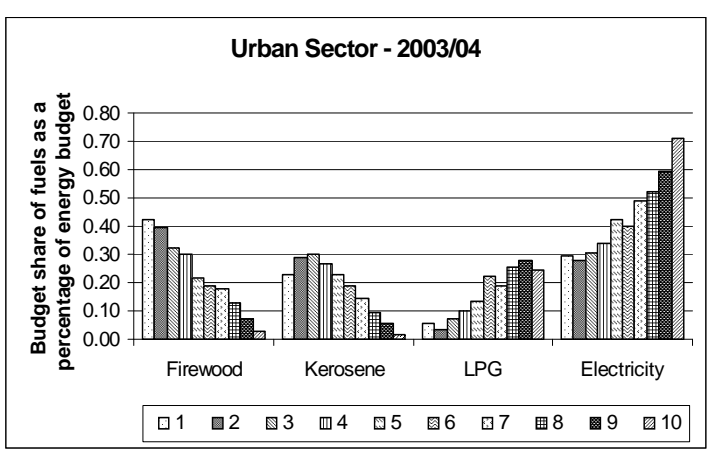

$\mathrm{E}$ 
Figure 4: Energy budget share of fuels - Rural sector

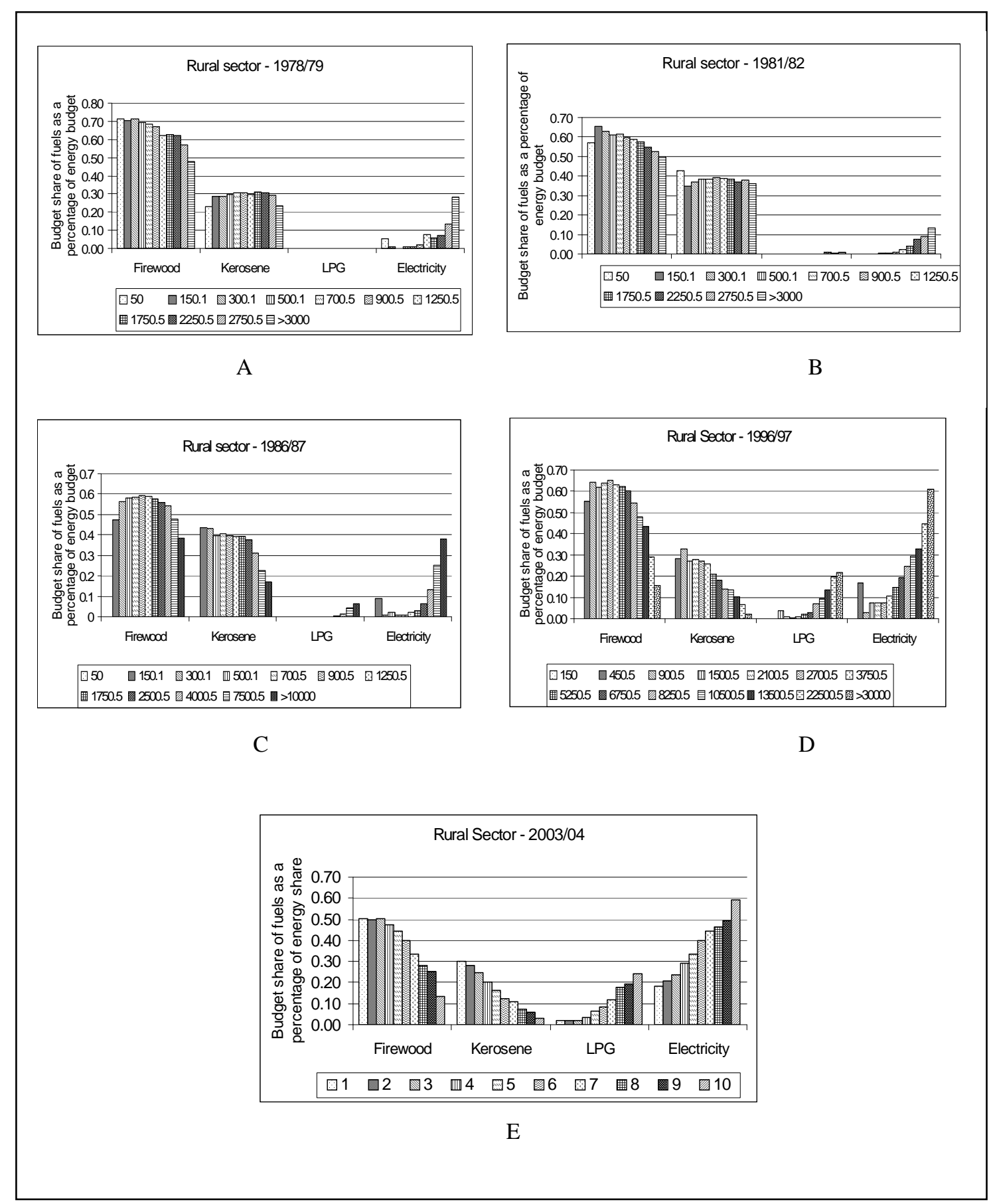


Figure 5: Energy budget share of fuels - Estate sector

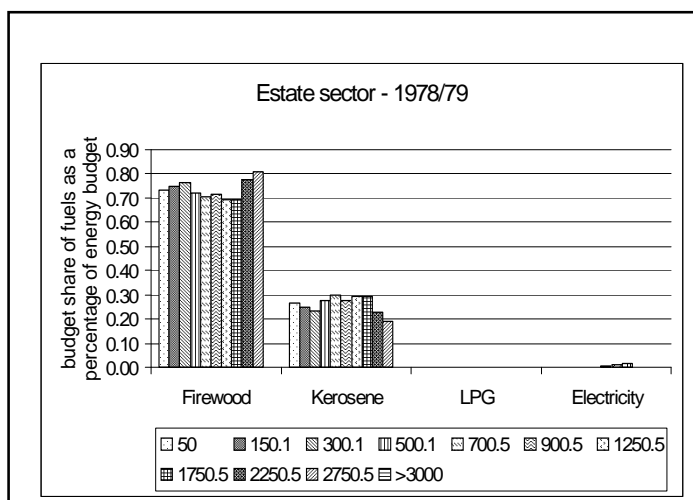

A

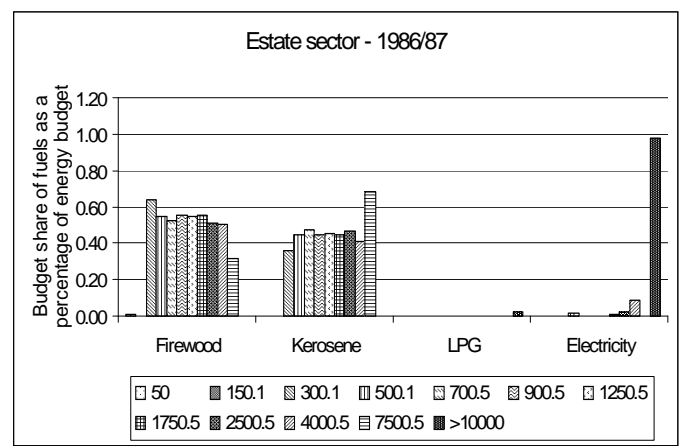

C

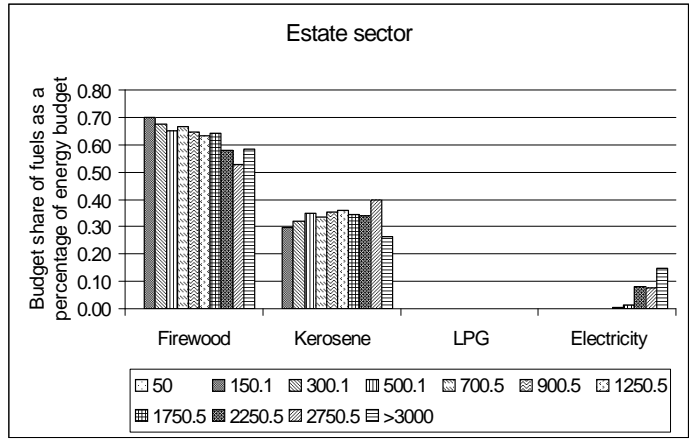

B

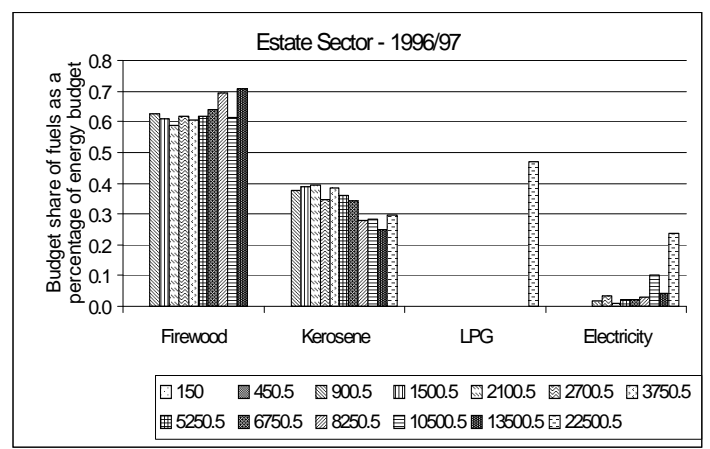

D

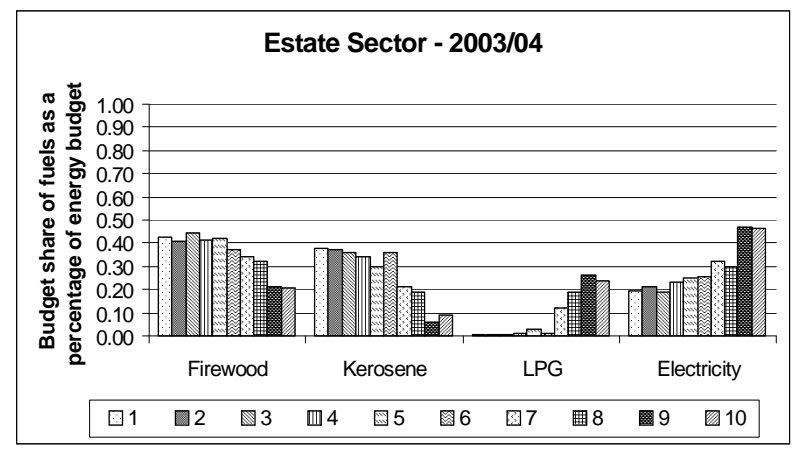

E 


\section{Overall fuel consumption pattern by sectors}

The overall fuel consumption shares by sectors over time are shown in figures 6 and 7. It could be observed that firewood has been the most popular source of energy among all the sectors, while its prominence has decreased with time. It is also obvious that the share of firewood has been decreasing and the share of LPG and electricity are increasing with time in the case of all sectors. Considering the urban sector, though firewood constituted a major share of the energy budget until 1986/87, its importance has been decreasing with time placing electricity as the main source of household energy followed by LPG in the urban sector.

In the rural sector too electricity is becoming the most popular source of energy. However, firewood too is consumed at the second highest level. The share of LPG is observed to be increasing while the share of kerosene is decreasing in the rural sector. Firewood predominates in the estate sector while a considerable share of energy is contributed by kerosene. Share of electricity in the estate sector has observed a huge hike between 1996/97 and 2003/04.

\section{Fuel switching pattern of households}

This section brings out the fuel transition pattern of households over time. As indicated in figure 6, the pattern of fuel switching in the case of all sectors shows a declining trend in the consumption of firewood and kerosene while the consumption of LPG and electricity have been increasing. This indicates that the Sri Lankan households are climbing the energy ladder longitudinally.

According to the results depicted in figures 7, it is apparent that both the urban and rural sectors are climbing the ladder (longitudinally), but the urban sector at a much faster rate compared to rural.

In the case of the estate sector, fuel switching had taken place mainly between firewood and kerosene until 1996/97. LPG and electricity constituted insignificant proportions until 1996/97. However, since the recent survey year the scenario has been changed and an indication of climbing the energy ladder is revealed in the estate sector too. 
70

Figure 6: Fuel switching of households - All sectors

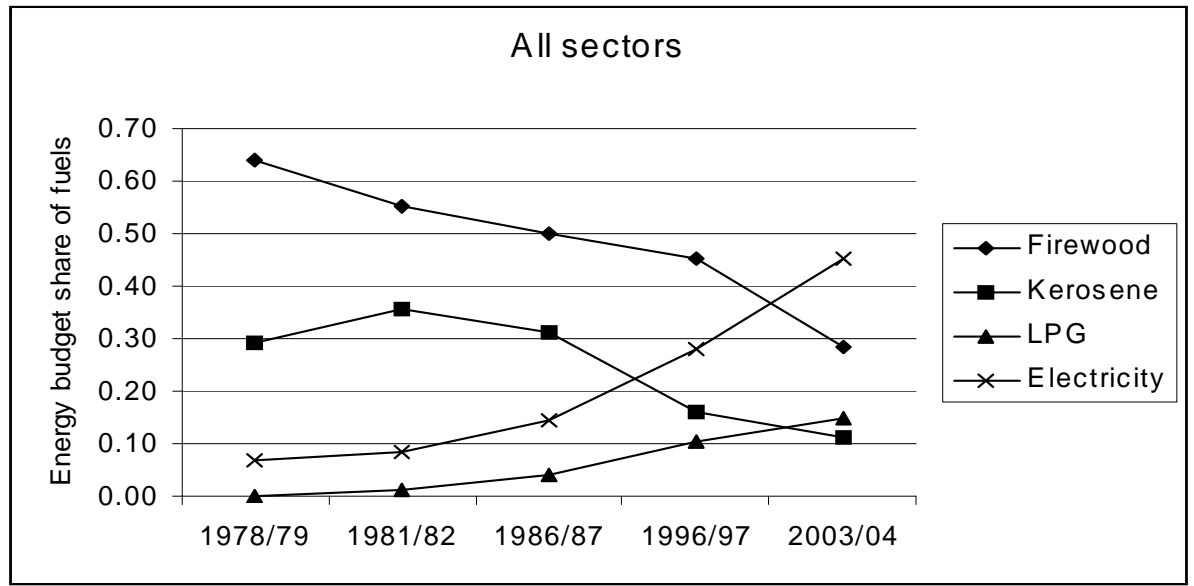

Figure 7: Fuel switching of households - By sector

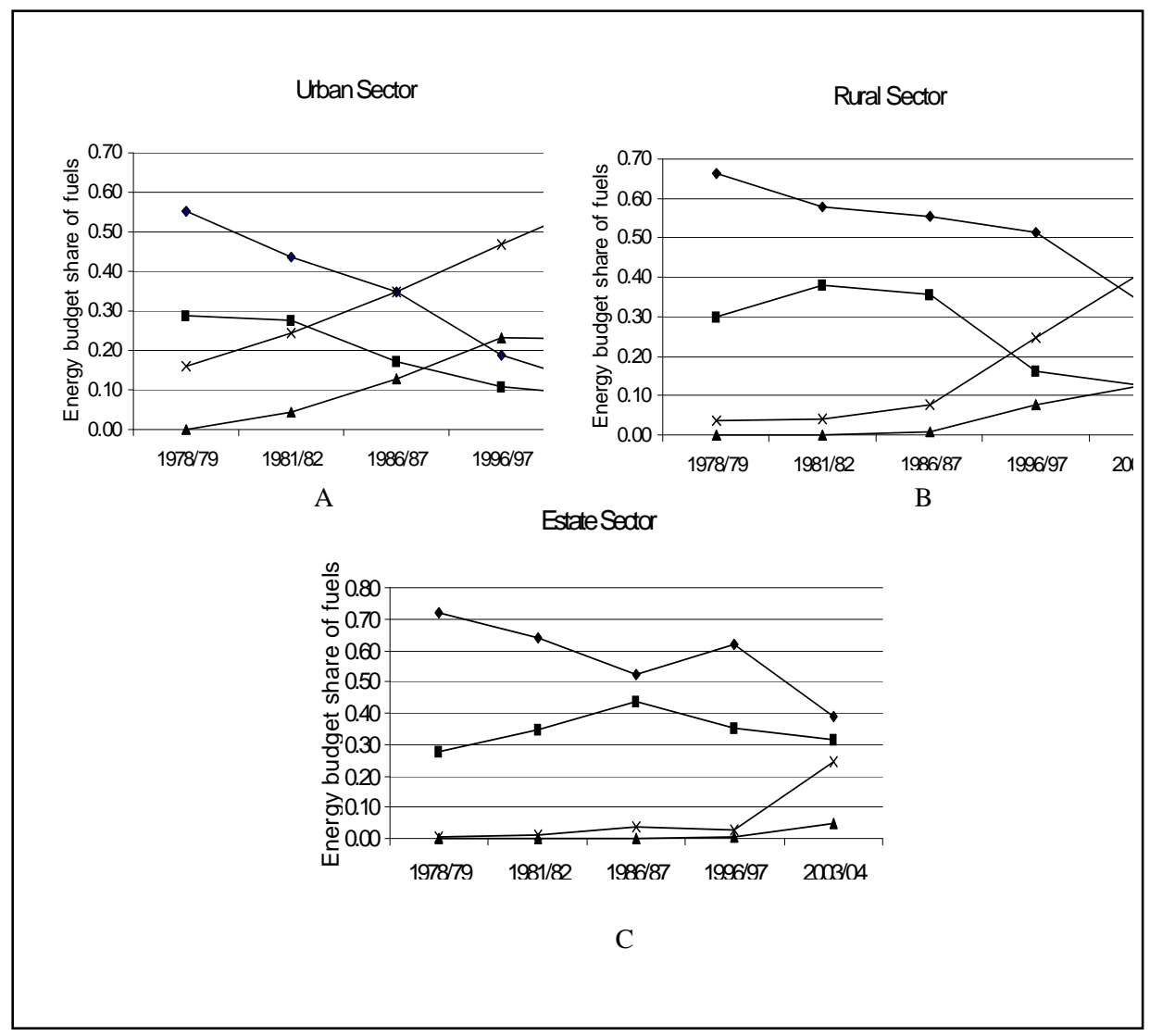




\section{Engle functions and budget elasticities}

The econometric estimates of the Engle functions are presented in table 2 . The coefficients are statistically significant at 0.05 level revealing that the relationship between fuel consumption and budget is significant. However, the adjusted $\mathrm{R}^{2}$ values are rather low implying that income does not fully explain the level of fuel consumption. Estimates for the estate sector were not significant, eliciting that the income is not the main factor that determines their energy choice.

Table 2: Econometric estimates of the Engle functions

\begin{tabular}{llccccc}
\hline Sector & \multicolumn{1}{c}{$\begin{array}{c}\text { Dependent } \\
\text { variable }\end{array}$} & $\begin{array}{c}\text { Coefficient } \\
\text { of Ln } \\
\text { (TEE) }\end{array}$ & $\begin{array}{c}\text { Standard } \\
\text { error }\end{array}$ & P-value & $\begin{array}{c}\text { Adjusted } \\
\text { R-squared }\end{array}$ & $\begin{array}{c}\text { No of } \\
\text { observations }\end{array}$ \\
\hline All & Firewood share & -0.084 & 0.0203 & 0.000 & 0.2069 & 53 \\
& Kerosene share & -0.067 & 0.0178 & 0.000 & 0.2045 & 53 \\
& LPG share & 0.048 & 0.0116 & 0.000 & 0.2789 & 43 \\
& Electricity share & 0.107 & 0.0256 & 0.000 & 0.2393 & 53 \\
\hline Urban & Firewood share & -0.123 & 0.0241 & 0.000 & 0.3333 & 51 \\
& Kerosene share & -0.057 & 0.0170 & 0.001 & 0.1725 & 51 \\
& LPG share & 0.041 & 0.0205 & 0.050 & 0.0716 & 41 \\
& Electricity share & 0.140 & 0.0223 & 0.000 & 0.4457 & 51 \\
\hline Rural & Firewood share & -0.086 & 0.0234 & 0.001 & 0.1960 & 52 \\
& Kerosene share & -0.058 & 0.0223 & 0.012 & 0.1010 & 52 \\
& LPG share & 0.049 & 0.0129 & 0.000 & 0.2459 & 42 \\
& Electricity share & 0.101 & 0.0303 & 0.002 & 0.1657 & 52 \\
\hline
\end{tabular}

The budget elaticities pertaining to the all island average fuel consumption which were calculated using the coefficients of the Engle function over time are shown in Table 3. Budget elasticity values for firewood and kerosene had negative signs as expected indicating that they are inferior goods, as explained by the energy ladder hypothesis too. LPG and electricity are considered to be normal goods with positive signs. 
The increasing absolute value of the budget elasticity for firewood with time denotes that as time passes households shift much faster from firewood with an increment in their income level compared to the earlier times. Kerosene budget elasticity shows a fluctuating pattern. This might be due to the change in price subsidy policies by the government, altering the purchasing power of consumers.

Budget elasticities for LPG show that it had been a luxury good until 1981/82 and has become a necessity in the recent past. The electricity budget elasticity has been decreasing with time pointing out its prime role as an energy source for the household in Sri Lanka.

Table 3: $\quad$ Budget elasticities of fuels (All sectors)

\begin{tabular}{llccc}
\hline Survey year & Firewood & Kerosene & LPG & Electricity \\
\hline $1978 / 79$ & -0.13 & -0.23 & - & 1.53 \\
$1981 / 82$ & -0.15 & -0.19 & 4.80 & 1.34 \\
$1986 / 87$ & -0.17 & -0.22 & 1.20 & 0.71 \\
$1996 / 97$ & -0.18 & -0.42 & 0.48 & 0.38 \\
$2003 / 04$ & -0.30 & -0.61 & 0.32 & 0.24 \\
\hline
\end{tabular}

Budget elasticities of individual fuels are given in table 4 for urban and rural sectors. They are negative and significant for firewood and kerosene and positive and significant for LPG and electricity.

Table 4: $\quad$ Budget elasticities of fuels (Sectoral differences)

\begin{tabular}{lllll|rrrr}
\hline \multicolumn{3}{c}{ Urban sector } & \multicolumn{4}{c}{ Rural sector } \\
\hline Survey year & Firewood & Kerosene & LPG & Electricity & Firewood & Kerosene & LPG & Electricity \\
\hline $1978 / 79$ & -0.22 & -0.20 & - & 0.87 & -0.13 & -0.19 & - & 2.52 \\
$1981 / 82$ & -0.28 & -0.21 & 1.03 & 0.56 & -0.15 & -0.15 & - & 2.52 \\
$1986 / 87$ & -0.35 & -0.33 & 0.31 & 0.40 & -0.16 & -0.16 & 4.90 & 1.26 \\
$1996 / 97$ & -0.65 & -0.52 & 0.18 & 0.30 & -0.17 & -0.36 & 0.61 & 0.40 \\
$2003 / 04$ & -1.23 & -0.71 & 0.18 & 0.24 & -0.25 & -0.45 & 0.38 & 0.25 \\
\end{tabular}

The higher absolute elasticity value for the urban sector compared to the rural sector and its increasing trend illustrate that urban households shift from firewood much faster than the rural households and the fuel transition takes place much rapidly with time. The fluctuating pattern of kerosene budget elasticities again reflects the changing purchasing power, influenced 
by government policies. However, the absolute elasticity values for kerosene are observed an increasing pattern after 1981/82.

In the urban sector LPG has become a necessity after 1986/87 and the elasticities have shown a decreasing trend while it was a luxury good in the rural sector until 1986/87 and is now a necessity. Electricity too shows a similar inclination.

\section{Concluding Remarks}

This paper examined how household choice of energy type could change with an increase in household income. Based on the data collected in several national household surveys between 1978/79 and 2003/04, the analysis shows that energy ladder hypothesis holds for the country. The study revealed that though Sri Lanka is moving up the energy ladder as a whole, sectoral differences exist. It is concluded that the income is the main factor that determines the fuel shifting pattern of the urban sector households except for the lower income classes. Also considering the rural sector, income level of households has turned to be the most important determining factor of fuel switching with time.

It is also obvious that income was not the main factor that determined fuel choice of the estate sector households since the energy ladder was not prominent in the cross-sectional view until 1996/97. It is the availability of fuels that would have mainly influenced their fuel choice. The fuel switching pattern of estate sector households in 2003/04 reveals that infrastructure development programs and electrification projects may have increased the availability of modern fuels in the estate sector, progressing it along the energy ladder. Since a significant improvement in the consumption of modern fuels in the estate sector was observed in 2003/04, it could be deduced that the estate sector would not take much longer time to switch to modern fuels.

Existence of differences in the fuel consumption pattern of households in different sectors shows that region of residence is another factor that affects the fuel choice of households. Availability of alternative fuels, prices of fuels and their substitutes and household characteristics could be other factors that determine the fuel choice of households. Kerosene consumption patterns of households particularly among the rural and estate sectors explicates that government pricing policies could also influence the fuel choice of households. 


\section{References}

Amacher, G., W. Hyde and B. Joshee (1993). Joint production and consumption in traditional households: fuelwood and crop residues in two districts of Nepal. Journal of Development Studies, 30(1): 206225. In S. Demurger and M. Fournier (2006).Rural Poverty and Fuelwood Consumption: Evidence from Labagoumen Township (China). [cited 23 September 2007]. <http://<papers.ssrn.com/ sol3/papers.cfm?abstract_id=553761>

Amacher, G., W. Hyde and K. Kanel (1996). Household fuelwood demand and supply in Nepal's tartai and mid-hills: choice between cash outlays and labour opportunity. World Development, 24(11), 17251736. In S. Demurger, and M. Fournier (2006). Rural Poverty and Fuelwood Consumption: Evidence from Labagoumen Township (China). [cited 23 September 2007]. <http://papers.ssrn.com/ sol3/papers.cfm?abstract_id=553761>

Amacher, G., W. Hyde and K. Kanel (1999). Nepali fuelwood production and consumption: regional and household distinctions, substitutuion and successful intervention. Journal of Development Studies, 35(4):13863. In S. Demurger and M. Fournier (2006). Rural Poverty and Fuelwood Consumption: Evidence from Labagoumen Township (China). [cited 23 September 2007]. <http://papers.ssrn.com/ sol3/papers.cfm?abstract_id=553761>

Arnold, M. J. E., G. Kohlin and R. Persson (2006). Woodfuels, livelihoods, and policy interventions: changing perspectives. World Development, 34(3): 596-611. In S. Demurger and M. Fournier (2006). Rural Poverty and Fuelwood Consumption: Evidence from Labagoumen Township (China). [cited 23 September 2007]. <http://papers.ssrn.com/sol3/papers.cfm?abstract_id=553761>

Athukorala, P.P.A.W., Gunathilake, H.M., Dharmasena, S., Gunarathne, L.H.P and Weerahewa, J. (2007). Estimation of household demand for electricity in Sri Lanka: A co integration Analysis. Personal Communication.

Baland, J. M., P. Bardhan, S. Das, D. Moorkherje and R. Sarkar (2005). The environmental impact of poverty: evidence from firewood collection in rural Nepal. In, S. Demurger and M. Fournier (2006). Rural Poverty and Fuelwood Consumption: Evidence from Labagoumen Township (China). [cited 23 September 2007]. Available from: http://papers.ssrn.com/sol3/ papers.cfm?abstract_id=553761 
Barnett, A. (2000). Energy and the fight against poverty. Department for International Development (Dfid), Livelihood sector report, UK. In M. Farsi, M. Fillippini and S. Pachauri (2005). Fuel Choices in Urban Indian Households. [cited 23 November 2007]. <www.saee.ch/ saee2004/Shonali_Mehdi_Massimo.pdf>

Bhatia, R. (1988). Energy pricing and household energy consumption in India. The Energy Journal, 9: 71-105. In, S. Gangopadhyay, B. Ramaswami and W. Wadhwa (2004). Reducing Subsidies on Household Fuels in India: How will it Affect the Poor? [cited 26 November 2007]. <www.idfresearch. org/pdf/fuel\%20subsidy.pdf>

Central Bank of Sri Lanka.Central bank annual reports. Various publications.

Chambwera, M. (2004). Economic analysis of urban fuelwood demand: the case of Harare in Zimbabwe. [cited 23 November 2007]. <www.cababstractsplus.org/ google/ abstract.asp? AcNo= 20043193027>

Davis, M. (1998). Rural household energy consumption: The effects of access to electricity- Evidence from South Africa. Energy Policy, 26(3): 207217. In M. Farsi, M. Fillippini and S. Pachauri (2005). Fuel Choices in Urban Indian Households. [cited 23 November 2007]. <www.saee.ch/saee2004/Shonali_Mehdi_Massimo.pdf>

Demurger, S. and M. Fournier (2006). Rural poverty and fuelwood consumption: Evidence from Labagoumen Township (China). [cited 23 September 2007]. Available from: <http://papers.ssrn.com/sol3/ papers.cfm?abstract_id=553761>

Deaton, A. and J. Mullbauer (1980). An almost ideal demand system. The American Economic Review, 70(3): 312-326. In, M. Chambwera (2004). Economic Analysis of Urban Fuelwood Demand: The Case of Harare in Zimbabwe. [cited 23 November 2007]. $<$ www.cababstractsplus.org/google/abstract.asp?AcNo=20043193027

Energy Information Administration (2005). International Energy Database. $<$ http://www.eia.doe.gov/>

Erdogdu, E. (2006). Electriciy demand analysis using cointegration and ARIMA modeling: A case study of Turkey. Energy Policy, 35(2007): 1129-1146. 
Gundimeda, H. and G. Kohlin (2003). Fuel demand elasticities for energy and environment studies: Indian sample survey evidence. Environmental economics unit, Department of Economics, Goteborg University, Sweden. In S. Demurger and M. Fournier (2006). Rural Poverty and Fuelwood Consumption: Evidence from Labagoumen Township (China). [cited 23 September 2007]. Available from: <http://papers.ssrn.com/sol3/papers.cfm? abstract_id=553761>

Helberg, R., T.C. Ardt and N.U. Sekhar (2000). Fuelwood consumption and forest degradation: a household model for domestic energy substitution in rural India. Land Economics, 76(2): 213-232. In S. Demurger and M. Fournier (2006). Rural Poverty and Fuelwood Consumption: Evidence from Labagoumen Township (China). [cited 23 September 2007]. <http://papers.ssrn.com/sol3/ papers.cfm?abstract_id=553761>

Hosier, R. H. and J. Dowd (1987). Household fuel choice in Zimbabwe-An empirical test of the energy ladder hypothesis. Resources and Energy, 9(1987): 347-361. In M. Farsi, M. Fillippini and S. Pachauri (2005). Fuel Choices in Urban Indian Households. [cited 23 November 2007]. <www.saee.ch/saee2004/Shonali_Mehdi_Massimo.pdf>

Hosier, R. H. and W. Kipondya (1993). Urban household energy use in Tanzania: Prices, substitutes and poverty. Energy Policy, 21(5): 45473.

International Energy Agency. (2005). Analysis of higher oil prices on the global economy. [cited 04 October 2007]. <www.iea.org/textbase/ papers/2004/high_oil_prices.pdf>

Kebede, B., A. Bekele and E. Kedir (2002). Can the urban poor afford modern energy? The case of Ethiopia. Energy Policy, 30: 1029-1045.

Masera, O.R., B.D. Saatkamp and D.M. Kammen (2000). From linear switching to multiple cooking strategies: A critique and alternative to the energy ladder model. World Development, 28(12): 2083-2103. In, M. Farsi, M. Fillippini and S. Pachauri (2005). Fuel choices in urban Indian households. [cited 23 November 2007]. <www.saee.ch/ saee2004/Shonali_Mehdi_Massimo.pdf>

Mekonnen, A., (1999). Rural household biomass fuel production and consumption in Ethiopia: A case study. Journel of Forest Economics, 5(1):69-97. In, Demurger, S. and Fournier, M. (2006). Rural poverty and fuelwood consumption: Evidence from Labagoumen Township 
(China). [Online]. [cited 23 September 2007]. Available from:〈http://papers.ssrn.com/sol3/papers.cfm?abstract_id=553761>

Prais, S.J. and H.S. Houthakker (1955). The analysis of fami;y budgets, with an application to two British surveys conducted in 1937-39 and their detailed results, Cambridge University Press. In E. Sadoulet and A. de Janvry. (1995). Quantitative Development Policy Analysis. Johns Hopkins University press.

Sadoulet, E. and A. de Janvry. (1995). Quantitative development policy analysis. Johns Hopkins University Press. 